\title{
STRATEGI PENGUATAN INDUSTRI KEUANGAN SYARIAH DI ERA MEA
}

\author{
Alif Edy Pamuji \\ Ekonomi Syariah, Universitas Islam Jember \\ alifugm@gmail.com \\ Ach Faqih Supandi \\ Ekonomi Syariah, Universitas Islam Jember \\ achfaqih@gmail.com
}

\begin{abstract}
Abstrak
Ekonomi Syariah Indonesia dalam Global Islamic Economy Index (GIEI) 2020/2021 menempati posisi ke-4 di dunia, meningkat satu peringkat dari tahun 2019. Kemudian, Islamic Finance Development Indicators (IFDI) 2020 dari The Islamic Corporation for the Development (ICD), The Islamic Development Bank (IsDB) dan Revintiv menempatkan Indonesia pada posisi kedua keuangan syariah dunia, naik dari posisi empat pada tahun lalu. Namun, Indonesia tidak bisa berbangga terlebih dahulu dengen pencapaian tersebut, karena masih banyak kekurangan-kekurangan yang menghampat peran IKS di era MEA yang semakin ketat persaingannya ini. Beberapa kekurangan tersebut berkaitan dengan dukungan pemerintah, kesadaran masyarakat, kualitas dan kuantitas sumber daya manusia, kekurangan modal dan pendanaan, pengawasan keuangan mikro, dan transparansi serta tata kelola yang baik. Oleh sebab itu diperlukan strategi utama agar dapat meningkatkan infrastruktur dan kemampuan sistem keuangan syariah, mengatasi kesenjangan yang ada, memperbaiki kinerja kelembagaan, menciptakan peluang baru di pasar domestik dan internasional, dan memosisikan Indonesia sebagai pemain utama dalam keuangan syariah di ASEAN.
\end{abstract}

\section{Kata Kunci: Strategi, Industri Keuangan Syariah (IKS), Masyarakat Ekonomi ASEAN (MEA)}

\begin{abstract}
Indonesia's Islamic economy in the 2020/2021 Global Islamic Economy Index (GIEI) occupies the 4th position in the world, an increase of one rank from 2019. Then, Islamic Finance Development Indicators (IFDI) 2020 from The Islamic Corporation for the Development (ICD), The Islamic Development Bank (IsDB) and Revintiv put Indonesia in the second position of Islamic finance in the world, up from fourth position last year. However, Indonesia cannot compete first with this competition, because there are still many shortcomings that hinder the role of IKS in the MEA era where competition is tight. Some of these shortcomings are related to government support, public awareness, quality and quantity of buman resources, lack of capital and finance, microfinance supervision, and transparency and good governance. Therefore, a main strategy is needed in order to improve the infrastructure and capabilities of the Islamic financial system, overcome the existing ones, improve institutional performance, create new opportunities in the domestic and international markets, and position Indonesia as a major player in sharia in ASEAN.
\end{abstract}

Keywords: Strategy, Islamic Finance Industry (IKS), ASEAN Economic Community (MEA) 


\section{Pendahuluan}

Tulisan ini dilatarbelakangi oleh keterlibatan Indonesia dalam Masyarakat Ekonomi ASEAN (MEA) yang sudah berjalan selama kurang lebih enam tahun. Masyarakat Ekonomi ASEAN (MEA) merupakan bentuk integrasi ekonomi ASEAN, negara-negara yang berada di kawasan Asia Tenggara (ASEAN) yang menerapkan sistem perdagangan bebas. (Editor, Peran Indonesia dalam Bidang Ekonomi di ASEAN, 2021). Selain meningkatkan tingkat kompetisi ekonomi di kawasan Asia Tenggara, MEA juga bertujuan untuk mempererat kerja sama ekonomi negara-negara ASEAN. Tujuan pembentukan MEA selama ini tercermin dalam sejumlah pilarnya. Keempat pilar itu adalah pertama, pasar dan basis produksi tunggal. Kedua, kawasan ekonomi berdaya saing tinggi. Ketiga, kawasan dengan pembangunan ekonomi yang merata dan berkeadilan. Terakhir, kawasan yang terintegrasi dengan ekonomi global (Editor, Tujuan Masyarakat Ekonomi ASEAN, Dampak \& Tantangan Bagi Indonesia, 2021)

Namun demikian, salah satu pilar yang paling banyak dan paling sering disorot dari konsepsi Masyarakat ASEAN adalah pilar ekonomi (MEA). Pasalnya, MEA merupakan suatu kebijakan ekonomi di antara negara-negara di Asia Tenggara untuk membebaskan rintangan dan halangan dalam hal perdagangan, arus modal, dan arus tenaga kerja. Hal ini selanjutnya, akan berdampak secara langsung kepada masyarakat. Salah satunya karena produk barang dan jasa negara-negara ASEAN lainnya dapat masuk dan bersaing dengan produk barang dan jasa domestik, khususnya pada dua belas sektor yang menjadi prioritas. (Khikmatin \& Setianingsih, 2021). Selain itu, MEA juga memungkinkan masuknya tenaga kerja asing terampil, khususnya tenaga kerja profesi. (Rijal, 2017)

Bagi Indonesia MEA dapat menjadi peluang besar untuk mengembangkan ekonomi menjadi lebih maju dan berkiprah di kancah regional Asia bahkan sampai dunia. Namun tantangan yang dimiliki Indonesia dari sisi internal masih sangat timpang jika dilihat dari perspektif negara ASEAN lainnya. Belum lagi tantangan dari segi eksternal dimana pesaing menjadi kompetitif dan tidak ada batas untuk terus bereksplorasi. Tantangan persaingan yang ketat tersebut menuntut Indonesia mempersiapkan amunisinya agar mampu bersaing di komunitas ekonomi ASEAN yang semakin terbuka.

Hasil sensus penduduk tahun 2020 masih menunjukkan bahwa di Indonesia penduduk muslim masih menjadi yang pertama, dengan 229 juta jiwa $(87,2$ persen dari total seluruh penduduk Indonesia 263 juta jiwa). Dengan keberadaan sebanyak itu, tentu tidak bisa dipungkiri Indonesia menjadi lahan basah untuk pengembangan ekonomi syariah. Bagi umat islam, ajaran yang berbasis syariah yaitu bersumber pada Al-Quran dan Al-Hadits, tidak terkecuali pada aktivitas ekonomi. Tidak hanya berkaitan dengan aturan makan dan minum yang harus halal, bersih dan sehat sebagaimana tertera dalam AlQuran dan Al-Hadits, namun juga Industri Keuangan Syariah (IKS) baik bank dan non bank, pariwisata halal dan hotel syariah. (Hidayat, 2018)

Melihat kondisi objektif tersebut, semakin nyata bahwa Indonesia memiliki peluang besar menjadi poros ekonomi syariah di dunia, Asia Tenggara khususnya. Indonesia juga memiliki kekayaan alam yang melimpah yang dapat dijadikan sebagai underlying transaksi Industri Keuangan Syariah (IKS) (BPS, 2021).Namun tentu tidak mudah, IKS Indonesia memiliki berbagai tantangan dan harus menunjukkan taringnya ke dunia. Terlebih sekarang persaingan tersebut bukan hanya dengan lembaga keuangan dalam negeri saja, mengingat Indonesia saat ini telah memasuki Masyarakat Ekonomi ASEAN (MEA). 
Dalam kaitannya dengan itu, implementasi MEA perlu dilihat sebagai peluang bagi ekonomi syariah khususnya industri keuangan syariah untuk menunjukkan eksistensinya. Dalam konteks Indonesia, implementasi MEA memberikan beberapa peluang bagi pengembangan berbagai dimensi yang berhubungan dengan ekonomi syariah. Sektor industri keuangan syariah yang telah hadir secara resmi lebih dari dua dasawarsa silam. Kendati pertumbuhannya semakin kuat setiap tahun, ukuran keseluruhan dan dampak dari industri ini terhadap ekonomi nasional tetap kecil dibandingkan dengan industri keuangan umum. Lanskap industri keuangan syariah di Indonesia sangatlah berbeda dengan negara lain seperti Malaysia dan GCC yang berfokus pada perbankan investasi dan pasar modal. (KNEKS, 2019).

Menurut Alamsyah (2012) dalam (Rijal, 2017), Indonesia merupakan negara yang memberikan peluang besar dalam pengembangan keuangan syariah di dunia, secara khusus di ASEAN. Peran keuangan syariah dalam pembangunan ekonomi Indonesia bukan hanya mengenai preferensi agama, melainkan melalui tujuan syariah (Maqasid al Shariah), keuangan syariah mempunyai kekuatan laten dalam memainkan peranan penting dalam pemberdayaan individu dan komunitas, mempromosikan budaya wiraswasta, berinvestasi dalam ekonomi yang riil dan berkelanjutan sehingga mendatangkan manfaat bagi masyarakat luas dan ekonomi Indonesia. Oleh karena itu diperlukan untuk menelusuri ulang bagaimana keadaan Industri Keuangan Syariah (IKS) Indonesia saat ini, dan bagaimana strategi penguatan Industri Keuangan Syariah (IKS) di Indonesia agar dapat berperan penuh di era Masyarakat Ekonomi ASEAN (MEA).

\section{Metode}

Tulisan ini merupakan penelitian kualitatif, dimana menggunakan metode deskriptif dengan pendekatan kualitatif. Sumber data merupakan data sekunder dimana dilakukan dokumentasi dengan telaah pustaka, telaah laman internet yang berhubungan dengan masalah penelitian ini.

\section{Hasil dan Pembahasan}

Hasil dan pembahasan dalam artikel ini akan membahas perkembangan Industri Keuangan Syariah (IKS) dan strategi penguatan Industri Keuangan Syariah (IKS) di era Masyarakat Ekonomi ASEAN (MEA) dengan studi literatur yang mendalam.

\subsection{Perkembangan Industri Keuangan Syariah (IKS) Indonesia Saat Ini}

Lembaga keuangan adalah suatu usaha yang setiap kegiatannya berkaitan mengenia uang, seperti menghimpun dana atau uang, kemudian penyaluran dan atau jasa-jasa keuangan yang lainnya. Menurut Dewan Syariah Nasional (DSN) sendiri, Industri Keuangan Syariah (IKS) adalah lembaga keuangan yang sudah mendapatkan izin dalam melakukan kegiatan operasionalnya sebagai lembaga keuangan untuk mengeluarkan produk dari keuangan syariah (Salman, 2017). Lembaga keuangan berkaitan erat dengan aktivitas ekonomi. Dengan adanya sistem perekonomian yang semakin terbuka ini, menjadikan setiap pelaku usaha bebas memasarkan produknya kemana saja. Melihat hal tersebut, tentunya akan menjadi peluang yang besar bagi pelaku usaha untuk meningkatkan dan memperbesar usahanya.

Pada masa sekarang Industri Keuangan Syariah (IKS) semakin berkembang pesat. Hal ini terbukti dengan semakin banyaknya lembaga jasa keuangan syariah, layanan dan produk hingga semakin meningkatnya infrastrutur di Industri Keuangan Syariah (IKS). Salah satu peluang yang dapat menjadikan Industri Keuangan Syariah (IKS)di Indonesia semakin meningkat ialah karena masyarakat Indonesia yang sebagian besar beragama 
islam, mulai tumbuh kesadaran untuk menggunakan layanan jasa keuangan syariah yang sesuai dengan prinsip islam. Agar Industri Keuangan Syariah (IKS) semakin dikenal di masyarakat dan dapat semakin berkembang maka diperlukan memanfaatkan peluangpeluang lain yang ada dengan maksimal.

Industri Keuangan Syariah (IKS) baik itu bank maupun non-bank dalam melaksanakan kegiatan operasionalnya selalu diawasi oleh sebuah lembaga yang dinamakan dengan Dewan Pengawasan Syariah. Dari pengertian ini dapat dijelaskan bahwa Industri Keuangan Syariah (IKS) adalah suatu lembaga yang mencakup segala aspek keuangan baik itu tentang persoalan perbankan ataupun kerjasama pembiayaan, keamanan dan asuransi perusahaan, dan lain sebagainya yang berlangsung di luar konteks perbankan. (Mensari \& Dzikra, 2017)

Industri Keuangan Syariah (IKS) di Indonesia diproyeksikan akan terus mengalami peningkatan mengingat mayoritas penduduk Indonesia adalah bergama Islam. Ini merupakan pangsa pasar yang sangat besar bagi Industri Keuangan Syariah (IKS), karena Indonesia juga merupakan negara dengan penduduk muslim terbanyak di dunia. Akan tetapi, hal ini tidak serta merta menjadikan Industri Keuangan Syariah (IKS) di Indonesia menjadi global player keuangan syariah. Hal ini dikarenakan masih rendahnya pengetahuan dan kesadaran masyarakat terhadap ekonomi syariah. Sehingga diperlukan adanya sosialisasi dan edukasi pada masyarakat. (Hidayat, 2018)

Pengembangan ekonomi syariah di Indonesia lebih bersifat market driven dan dorongan botton up dalam memenuhi kebutuhan masyarakat. Dengan demikian, pengembangan ekonomi syariah di Indonesia lebih bertumpu pada sektor riil, dan ini merupakan suatu kelebihan tersendiri bagi Industri Keuangan Syariah (IKS) di Indonesia. Hal ini yang menjadikan Industri Keuangan Syariah (IKS) lebih tahan menghadapi krisis ekonomi tahun 1998 dibandingkan dengan lembaga keuangan konvensional. (Hidayat, 2018)

Sementara itu, Industri Keuangan Syariah (IKS) Indonesia dalam Global Islamic Economy Index (GIEI) 2020/2021 menempati posisi ke-4 di dunia, meningkat satu peringkat dari tahun 2019. Kemudian, Islamic Finance Development Indicators (IFDI) 2020 dari The Islamic Corporation for the Development (ICD), The Islamic Development Bank (IsDB) dan Revintiv menempatkan Indonesia pada posisi kedua keuangan syariah dunia, naik dari posisi empat pada tahun lalu. Peningkatan peringkat Indonesia di 2020 sangat dipengaruhi oleh indikator Pengetahuan (Knowledge), yang didalamnya termasuk peningkatan pendidikan dan riset keuangan syariah. (Andika \& Aldy, 2020)

Perkembangan Industri Keuangan Syariah (IKS) baik bank atapun non bank belakangan ini sangat masif pergeraka nnya. Berikut pemaparan perkembagan LKS bank dan non bank saat ini:

\section{a. Perbankan Syariah}

Sektor perbankan syariah menjadi salah satu sorotan dalam perkembangan Industri Keuangan Syariah (IKS). Perkembagannya pun pada dasarnya menunjukkan tren yang positif, dari segi pangsa pasar data per September 2020 pangsa pasar perbankan syariah Indonesia mencapai 6,24\% dibandingkan dengan tahun 2015 hingga 20 tahun terakhir stagnan pada angka di bawah 5\%. Meningkatnya pangsa pasar ini tentunya dipengaruhi oleh berbagai faktor di antaranya kemajuan teknologi, perubahan makro dan mikro ekonomi Indonesia, dan demografi Indonesia. (OJK, 2020).

Perkembangan bank syariah jika dilihat dari jumlah jenisnya ialah 14 Bank Umum Syariah dengan 1943 kantor, kemudian 20 Unit Usaha Syariah dengan 390 kantor, dan 162 Bank Pembiayaan Rakyat Syariah dengan 626 kantor. Dengan jumlah tersebut secara umum perbankan syariah memiliki total aset sebesar Rp575,85 triliun. Pertumbuhan aset perbankan syariah ini tumbuh sebesar 14,32\% (yoy) yang ditopang 
oleh pertumbuhan Pembiayaan Yang Disalurkan (PYD) dan Dana Pihak Ketiga (DPK) yang masing-masing mengalami pertumbuhan sebesar 8,68\% (yoy) dan 15,58\% (yoy). Dengan demikian PYD dan DPK perbankan syariah masing-masing mencapai Rp384,65 triliun dan Rp460,51 triliun pada September 2020. (Otoritas Jasa Keuangan, 2021)

Kondisi perbankan selama pandemi Covid-19 cukup baik, termasuk perbankan syariah. Ini bisa dilihat data dari Otoritas Jasa Keuangan antara lain melalui indikator penyaluran dana, total asset, Capital Adequacy Ratio (CAR) dan Loans to Deposits Ratio (LDR) tahun 2019 dan 2020. Aset tahun 2020 mengalami kenaikan 13,14 persen dari tahun 2019. Penyaluran dana pada akhir tahun 2020 naik 8,12 persen dari tahun 2019. Dari sisi CAR mengalami kenaikan 5,01 persen. Sedangkan LDR mengalami penurunan 1,99 persen. (Otoritas Jasa Keuangan, 2021)

Dengan gambaran objektif di atas menunjukkan perkembangan bank syariah saat ini masih dibilang baik dan stabil. Namun, masih terdapat isu strategi yang harus diselesaikan jika ingin memajukan perbankan syariah di Indonesia. Berdasarkan Kajian Transformasi Perbankan Syariah yang disusun pada tahun 2018, terdapat beberapa isu strategis yang masih menghambat akselerasi pertumbuhan bisnis perbankan syariah, antara lain belum adanya diferensiasi model bisnis yang signifikan, kualitas, dan kuantitas SDM yang kurang optimal serta rendahnya tingkat literasi dan inklusi. (Otoritas Jasa Keuangan, 2021)

Pertama, potensi pasar yang cukup besar tidak dibarengi dengan pertumbuhan pangsa pasar yang besar, mengingat mayoritas penduduk Indonesia yang beragama Islam. Kedua, Kondisi SDM perbankan syariah, baik dari sisi kuantitas maupun kualitas, serta teknologi informasi yang belum dapat mendukung pengembangan produk dan layanan. (Roadmap Perbankan Syariah 2018- 2019); Ketiga, berdasarkan data statistik perbankan Indonesia periode Desember 2014 sampai Mei 2017, jika dibandingkan kinerja perbankan syariah dengan perbankan konvensional, dalam berbagai ukuran penilaian kinerja industri perbankan, yaitu CAR, ROA, BOPO, LDR/FDR, NIM/NOM, NPL/NPF berada dibawah kinerja konvensional. Keempat, upaya perbaikan regulasi belum maksimal sehingga masih harus terus menerus dilakukan agar terjadi keselarasan dalam operasional perbankan syariah dengan kondisi-kondisi yang terus berubah dalam perekonomian secara makro. Kelima, aspek penelitian dan pengembangan yang masih harus terus dikembangkan untuk mengetahui kondisi terbaru, baik menyangkut peluang, tantangan, maupun kelebihan dan kekurangan yang dimiliki. Terakhir, edukasi dan sosialisasi yang belum inklusif dan menyentuh masyarakat luas sehingga harus terus dilakukan agar pertumbuhan dan keberlangsungan industri keuangan dan perbankan syariah dapat sesuai yang ditargetkan.

\section{b. Pasar Modal Syariah}

Pasar modal syariah adalah salah satu subsektor dalam Industri Keuangan Syariah (IKS) yang berfungsi sebagai intermediasi sirkulasi modal. Secara global, industri pasar modal syariah mencakup penerbitan saham syariah, obligasi syariah atau sukuk, dan reksa dana syariah (Omar et al., 2013). Pasar modal syariah, seperti halnya pasar modal konvensional, merupakan komponen penting dalam sebuah sistem keuangan secara keseluruhan. Dalam praktiknya, industri pasar modal syariah mengacu pada prinsipprinsip syariah yang operasionalnya secara umum sejalan dengan konsep Islam dalam pemerataan dan peningkatan kemakmuran. 
Pasar modal syariah di Indonesia telah berkembang selama dua dekade sejak pertama kali diluncurkannya produk reksa dana syariah pada tahun 1997. Perkembangan ini selanjutnya diikuti dengan munculnya Jakarta Islamic Index (JII) pada tahun 2000 dan diterbitkannya obligasi syariah mudharabah pada tahun 2002. Dalam rangka memberikan kepastian hukum, Bapepam - LK selaku regulator pasar modal menerbitkan paket regulasi pasar modal syariah pada tahun 2006 dan daftar efek syariah (DES) pada tahun 2007. Pada tahun 2008, pemerintah pertama kali menerbitkan surat berharga syariah negara (SBSN) (Roadmap Pasar Modal Syariah 2015-2019).

Menurut data MEKSI, jumlah investor dan perdagangan kinerja pasar modal syariah Indonesia telah tumbuh signifikan dalam tujuh tahun terakhir, dengan rata-rata pertumbuhan jumlah investor lebih dari 100\% per tahun dan pasar saham lebih dari 50\%. Pada bulan Maret 2019, Kustodian Sentral Efek Indonesia mengembangkan sistem penyimpanan dan transaksi surat berharga yang baru jasa penyelesaian yang sesuai dengan prinsip syariah. Sebulan Bursa Efek Indonesia kemudian meluncurkan Wakaf Saham yang dapat diperdagangkan fasilitas, jenis baru filantropi Islam terkait dengan saham.

Dalam pasar modal syariah terdapat beberapa instrumen diantaranya saham syariah. perkembangan saham syariah jika dilihat dari jumlah efek syariah cukup meningkat. Jumlah saham syariah dari tahun ke tahun mengalami tren kenaikan yang positif sebagaimana diperlihatkan pada grafik.

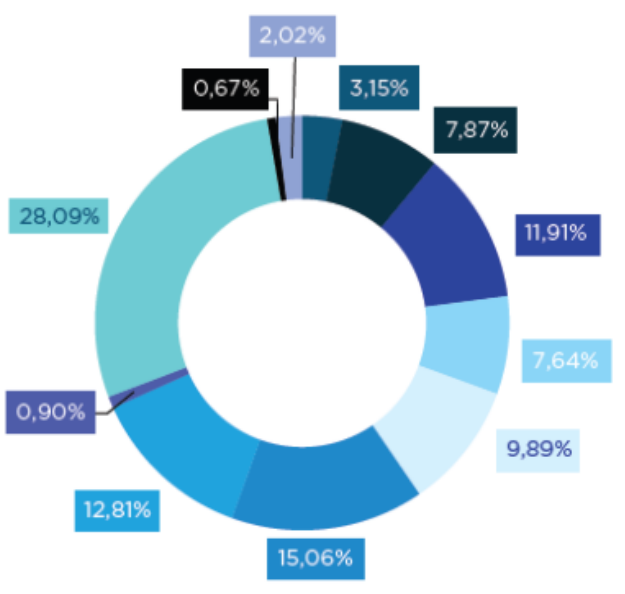

Sumber: OJK 2019

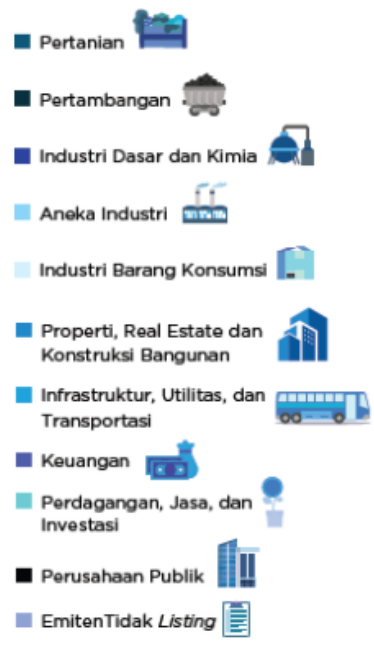

Dalam hubungannya dengan sektor industri halal, efek-efek syariah sektoral mempunyai peran terhadap standar halal yang akan diberikan ketika perusahaan akan melalui proses seleksi. Efek-efek syariah yang diterbitkan oleh sektor perusahaan konsumsi seharusnya juga melalui proses seleksi kualitatif yang dilakukan oleh Badan Penyelenggara Jaminan Produk Halal (BPJPH). Namun, teknis inipun belum memiliki kejelasan legalitas. Di sisi lain, jumlah efek syariah perlu ditingkatkan lagi dengan mendorong perusahaan-perusahaan yang bergerak di sektor halal untuk menambah aspek permodalannya.

Instrumen lainnya yaitu Sukuk Korporasi dan Sukuk Negara. Pasar sukuk tumbuh pesat setelah diresmikannya UU Nomor 19 Tahun 2008 tentang Surat Berharga Syariah Negara yang kemudian diikuti oleh penerbitan sukuk negara perdana (seri IFR) di pasar 
domestik dengan total nilai penerbitan sebesar Rp 4,67 triliun (Direktorat Pembiayaan Syariah Kementerian Keuangan, 2018). Setelah momentum tersebut, pemerintah Indonesia melalui Kementerian Keuangan mengeluarkan sukuk negara sebagai instrumen untuk membiayai infrastruktur. Selama sepuluh tahun sejak debutnya, pemerintah saat ini telah rutin menerbitkan sukuk negara baik di level nasional maupun internasional. Beberapa seri yang telah terbit di pasar adalah sukuk ritel, sukuk negara internasional (SNI), dan sukuk dana haji.

Indonesia tetap menjadi penerbit Sukuk terbesar di dunia dalam hal berharga. Memperkuat statusnya sebagai pelopor dalam penghijauan berdaulat Pasar Sukuk, negara menerbitkan yang kedua yang sama pada Februari 2019, dan Sukuk ritel hijau kemudian pada November. Di sana berencana untuk menerbitkan setidaknya dua lagi pada tahun 2020. Pada Maret 2020, pemerintah menerbitkan Sukuk Wakaf uang tunai perdana, mengumpulkan Rp50,85 miliar (US\$3,55 juta) pada dasar penempatan. Hasil dari Sukuk didedikasikan untuk mengembangkan aset Wakaf baru Badan Wakaf Indonesia, termasuk sebuah rumah sakit. Menurut Kementerian Keuangan, penerbitan Sukuk korporasi domestik meningkat dari Rp10,63 triliun (US\$751,25 juta) pada 2018 (setahun penuh) menjadi Rp9,4 triliun (US\$663,68 juta) selama paruh pertama tahun 2019 saja.

Pada Agustus 2019, kementerian mengubah peraturan tentang penerbitan dan penjualan Sukuk negara dalam valuta asing di pasar perdana internasional untuk meningkatkan partisipasi bank lokal di pasar Sukuk Negara. Di bawah peraturan baru ini, lembaga keuangan domestik sekarang diizinkan untuk menjadi pengelola bersama Sukuk negara, meskipun mereka hanya beroperasi di dalam negeri. Pada Agustus 2020, OJK meluncurkan pasar modal syariah Indonesia yang baru untuk 2020-24 - pembaruan dari sebelumnya untuk 2014-19, dan berfokus pada pengembangan infrastruktur yang terintegrasi dengan industri Halal Tanah Air.

Penerbitan Sukuk tersebut mencapai tingkat kupon terendah untuk Sukuk internasional yang keluar dari Indonesia dan juga disebut-sebut sebagai Sukuk global terbesar dengan tenor 30 tahun di kawasan. "Transaksi ini mendapat permintaan luar biasa dari investor global yang berkualitas dan beragam memperkuat pasar Sukuk dan menunjukkan kepercayaan investor yang kuat di Indonesia," kata pemerintah. Itu melihat pesanan dari investor dari Timur Tengah, Malaysia, AS, dan Eropa.

Tahap pertama dari seri — Sukuk lima tahun — adalah penerbitan hijau yang didedikasikan oleh pemerintah untuk pembiayaan berkelanjutan guna mendukung komitmennya untuk mengatasi perubahan iklim. Fasilitas Green Sukuk ini merupakan penerbitan ketiga Indonesia di pasar internasional, dengan yang terbaru adalah fasilitas Green Sukuk Ritel yang diterbitkan pada akhir tahun 2019. Rangkaian tersebut sejalan dengan rencana pembiayaan Indonesia 2020 yang mencakup ketentuan untuk menangani dampak pandemi COVID-19 serta upaya untuk semakin memperkuat posisi negara di pasar keuangan syariah internasional dan juga untuk mendukung perkembangan keuangan syariah di Indonesia. Asia, catat pemerintah.

Perkembangan pesat pada inovasi jenis instrumen juga terjadi pada penerbitan sukuk negara setelah tahun 2010. Di tahun 2012, pemerintah melakukan lelang reguler sukuk negara seri PBS dan SPN-S, lelang sukuk negara tambahan (green shoe option), dan SNI dengan format Islamic GMTN. Selanjutnya pada tahun 2013, pemerintah pertama kalinya mulai menerbitkan sukuk berbasis proyek dengan nama project based 
sukuk (PBS). Satu tahun setelahnya, pemerintah menerbitkan sukuk global kelima dan keenam diterbitkan pada periode 2014-2015. Tahun 2016, sukuk negara ritel SR-008 diterbitkan oleh pemerintah dan dilanjutkan dengan menerbitkan Sukuk ritel SR-009 di tahun 2017. Pada tahun 2018, pemerintah pertama kalinya menerbitkan green sukuk sebagai kontribusi dalam SDGs.

Performa yang baik pada sukuk negara sayangnya belum diikuti oleh industri korporasinya. Pemerintah terlihat lebih fokus dalam menerbitkan sukuk negara dibandingkan korporasi. Padahal ketika keduanya mempunyai dukungan yang sama, sukuk Indonesia dapat mengungguli negara-negara lain. Permasalahan utama dalam pengembangan sukuk korporasi terletak sekurang-kurangnya pada lima hal yaitu ketidakjelasan pajak (regulasi), minimnya pemahaman emiten tentang obligasi syariah (sukuk), minimnya SDM profesional (pelaku pasar), likuiditas di pasar sekunder dan kurangnya sosialisasi. Masalah lain yang saat ini menjadi fokus pemerintah adalah literasi yang masih rendah akan produk sukuk korporasi dibandingan dengan instrumen keuangan syariah lainnya (Strategi Nasional Literasi Keuangan Indonesia OJK, 2013). Oleh karena itu, perlu dukungan pemerintah mendorong perusahaan untuk menerbitkan sukuk dengan biaya yang murah, pajak intensif, dan lingkage dengan perusahaanperusahaan yang bergerak di sektor halal, meningkatkan jumlah penerbitan dan outstanding sukuk di dunia, serta bersaing dengan sukuk-sukuk korporasi yang ada di dunia.

Instrumen pasar modal syariah selanjutnya adalah Reksa dana syariah. Reksa dana syariah menunjukkan tren yang meningkat meskipun pertumbuhannya lambat. Berdasarkan data statistik reksa dana syariah dari Otoritas Jasa Keuangan (OJK), pertumbuhan nilai aktiva bersih (NAB) reksa dana ini mencapai 38,25 persen (ytd) pada Agustus 2017 dibandingkan posisi Desember 2016. Di samping itu, jumlah produk reksa dana syariah juga tercatat mengalami peningkatan dari 136 produk pada Desember 2016 menjadi 160 produk per Agustus 2017. Jika dibandingkan 2010, jumlah produk reksa dana syariah hanya 48 produk, dan total NAB sebesar Rp 5,22 triliun.

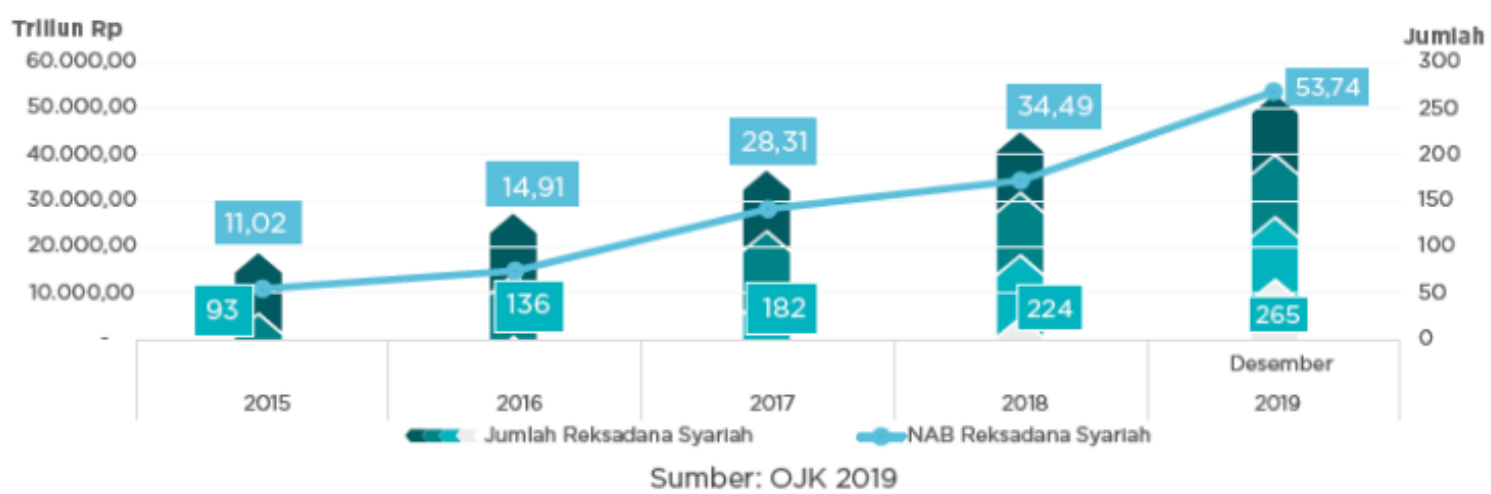

Gambar 4. Perkembangan Reksa Dana Syariah

Sumber: OJK, 2019

Kendala pengembangan reksa dana syariah sebagian besar dipengaruhi oleh rendahnya pemahaman masyarakat tentang berinvestasi di syariah. Masyarakat beranggapan investasi melalui reksa dana syariah diperuntukkan bagi umat Muslim saja. Namun saat ini, di era digital, masyarakat juga mulai sadar tentang reksa dana syariah 
karena banyak market place yang menawarkan fitur beli reksa dana termasuk yang syariah. Produk reksa danapun saat ini tidak hanya terfokus pada orientasi komersil, beberapa lembaga aset manajemen telah mengeluarkan reksa dana endownment atau wakaf. Yayasan Dompet Dhuafa Republika dan PT BNI Asset Management bekerja sama dalam penghimpunan dana wakaf produktif melalui investasi di reksa dana syariah.

Sukuk negara dapat menjadi salah satu instrumen yang berperan sebagai alternatif pembiayaan bagi pengembangan industri halal selain dari sektor perbankan. Dalam hal ini proyek-proyek yang memiliki bentuk fisik, berada di bawah pengawasan $\mathrm{K} / \mathrm{L}$ pusat, dan masuk dalam APBN memiliki potensi untuk didanai sukuk negara. Potensi pembiayaan yang lebih besar lagi juga tersedia pada instrumen sukuk korporasi dan sukuk regional. Berbeda dengan sukuk negara, keduanya memiliki potensi pembiayaan yang luas karena tidak harus melalui mekanisme pengajuan ke APBN. Sukuk korporasi saat ini baru memiliki pangsa pasar di kisaran 5 persen sehingga masih banyak ruang penerbitan yang belum terealisasi.

Selain sukuk, instrumen lain dalam pasar modal syariah seperti saham syariah dan reksa dana syariah juga dapat digunakan sebagai alternatif bagi perusahaan yang membutuhkan tambahan pembiayaan dari publik. Syaratnya, perusahaan memenuhi regulasi dan ketentuan yang sudah ditetapkan. Berbeda dengan sukuk, dana yang diperoleh dari kedua instrumen ini tidak langsung berdampak pada pengembangan industri halal. Namun seluruhnya berpartisipasi untuk mendukung ekonomi syariah di Indonesia.

\section{c. Industri Keuangan Lainnya}

Pada sektor industri keuangan lainnya peneliti akan memaparkan perkembangan asuransi syariah, zakat, dan wakaf. Perkembangan asuransi syariah di Indonesia dalam lima tahun terakhir menunjukkan tren peningkatan dari sisi aset meskipun terdapat perlambatan dari sisi pertumbuhannya. Data yang dilansir OJK dalam Statistik IKNB Syariah menunjukkan bahwa hingga Agustus 2018, asuransi syariah memiliki total aset sebesar Rp 41,68 triliun dengan rincian Rp 34,35 triliun pada asuransi umum, Rp 5,48 triliun pada asuransi jiwa, dan Rp 1,85 triliun pada reasuransi. Perlambatan pertumbuhan sendiri telah dimulai pada tahun 2017 dengan pertumbuhan aset sebesar 21,89 persen dari tahun sebelumnya. Angka ini lebih rendah daripada pertumbuhan di tahun 2016 yang tercatat sebesar 25,36 persen.

Saat ini, data terbaru menunjukkan bahwa total aset industri asuransi syariah pada tahun 2020 mengalami penurunan sebesar 2,23\% (yoy) menjadi Rp 44,44 triliun, yang dipengaruhi oleh penurunan investasi sebesar 6,29\%. Hal itu dikarenakan portofolio investasi asuransi syariah didominasi oleh investasi di pasar modal sehingga terdampak penurunan kinerja dari pasar modal Indonesia. (Ardianto, 2021)

Kondisi itu tercermin dari aset industri asuransi jiwa syariah yang susut 3,12\% (yoy) menjadi Rp 36,31 triliun. Sedangkan asuransi umum syariah masih mampu tumbuh tipis 1,88\% (yoy) menjadi Rp 6,01 triliun. Diikuti pertumbuhan aset dari perusahaan reasuransi syariah sebesar 2,22\% (yoy) menjadi Rp 2,10 triliun. Kendati total aset cenderung menurun, tapi kontribusi bruto masih mampu meningkat 3,84\% (yoy) menjadi Rp 17,34 triliun.. (Ardianto, 2021)

Pangsa pasar sektor asuransi syariah dibandingkan dengan sektor asuransi konvensional periode 2014 sampai 2018 konsisten berada di atas 5 persen. Perlambatan pertumbuhan sempat terjadi di tahun 2015 dengan pertumbuhan sebesar 5,13 persen, 
turun 15 bps dari tahun sebelumnya. Selanjutnya di tahun 2018, pangsa pasar tersebut meningkat hingga 6,16 persen dan merupakan pangsa pasar tertinggi sejak kemunculan asuransi syariah. (KNEKS, 2019). Saat ini tahun 2020 pangsa pasar aset industri asuransi syariah baru sekitar Rp 40 triliun atau 5\% atau triliun dari industri asuransi konvensional. (Ardianto, 2021)

Selanjutnya perkembangan zakat. Data Statistik Zakat Nasional tahun 2017 menunjukkan bahwa realisasi penghimpunan dana zakat tertinggi dilakukan oleh kelompok OPZ dari BAZNAS tingkat Kabupaten/Kota, yaitu sebanyak 77 persen dari total penghimpunan, diikuti oleh kelompok LAZ sebanyak 16 persen. Berikutnya kelompok BAZNAS Provinsi sebanyak 10 persen dan BAZNAS pusat sebanyak 3 persen.

Ditinjau dari trennya, penghimpunan zakat di Indonesia terus menunjukkan peningkatan setiap tahun. Data BAZNAS menunjukkan bahwa dalam 10 tahun terakhir (2008-2017), dana zakat telah tumbuh sebesar 576 persen dari Rp 920 miliar pada tahun 2008 menjadi Rp 6,22 triliun pada tahun 2017 atau tumbuh rata-rata 57,6 persen per tahun. Namun demikian, tingkat pertumbuhan ini cenderung fluktuatif. Hal ini karena realisasi penghimpunan tiap tahun dapat bergantung pada peristiwa yang terjadi di tahuntahun tertentu. Misalnya pada tahun 2005 dan 2007. Ketika itu pertumbuhan penghimpunan mencapai hingga masing-masing 96,90 persen dan 98,30 persen karena adanya bencana tsunami Aceh dan gempa Yogyakarta.

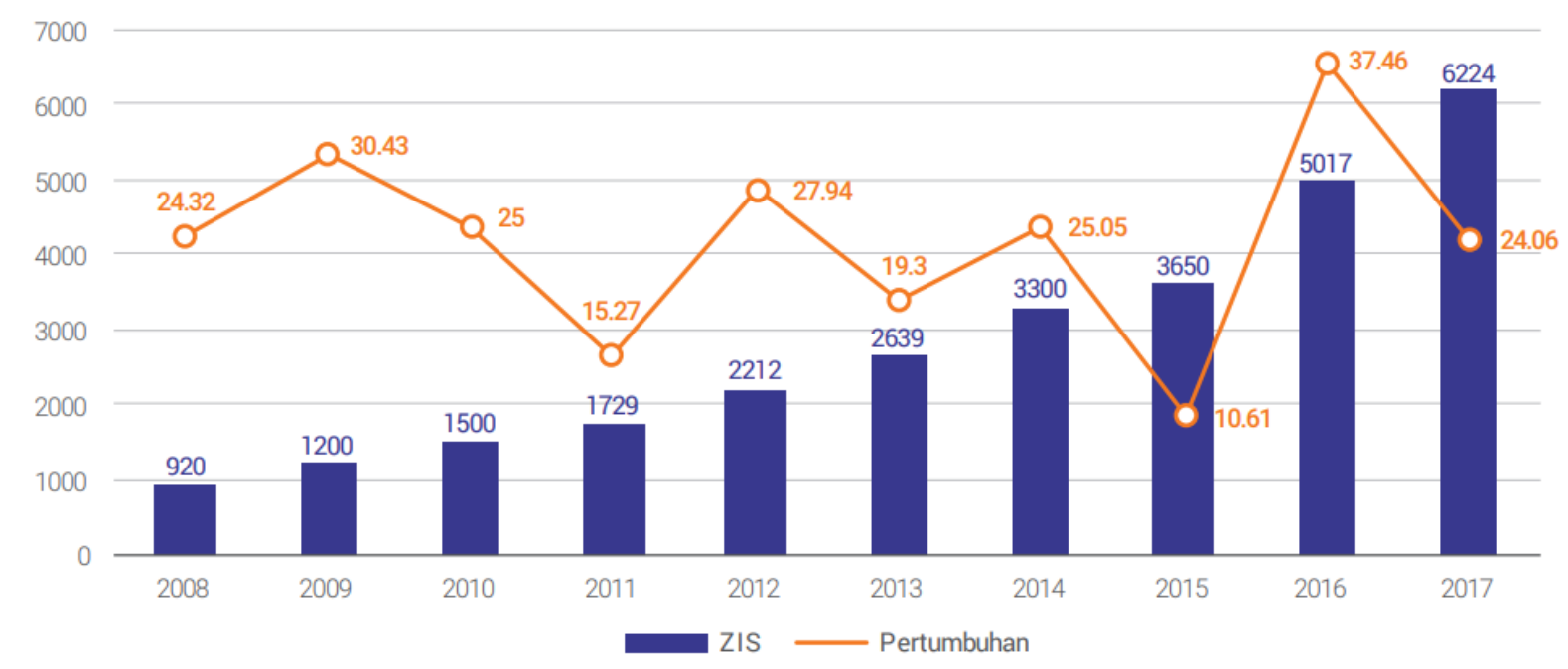

Apabila dikaitkan dengan potensinya, realisasi penghimpunan zakat sejumlah Rp 6,22 Triliun tersebut masih tergolong kecil. Firdaus, Beik, et al (2012) menyatakan potensi zakat di Indonesia pada tahun 2012 mencapai Rp 217 triliun per tahun atau 3,4\% dari PDB. Artinya realisasi penghimpunan zakat tersebut masih di angka 2,86 persen. Beberapa faktor yang mungkin mempengaruhi rendahnya realisasi penghimpunan zakat ini di antaranya adalah minimnya kesadaran wajib zakat, masih rendahnya insentif bagi wajib zakat pada saat membayar zakat, masih adanya ketidakpercayaan masyarakat terhadap lembaga zakat, dan dampak distribusi zakat yang masih belum maksimal (BAZNAS, 2018). Dari penyalurannya, dalam tiga tahun terakhir lebih dari 65 persen dana zakat di Indonesia secara konsisten telah disalurkan untuk mustahik fakir dan miskin. Hal ini menandakan bahwa 65 persen dana zakat di Indonesia telah 
didistribusikan untuk mendukung penanganan fakir miskin di Indonesia sesuai dengan amanat pengelolaan zakat sebagaimana ditegaskan dalam UU No 23 tahun 2011 yaitu untuk pengentasan kemiskinan. Penyaluran tertinggi setelah asnaf fakir miskin adalah mustahik fi sabilillah. Penerima penyaluran dana zakat terbanyak selanjutnya adalah asnaf amil zakat. Dana zakat selain digunakan untuk menggaji upah para amil zakat, juga disalurkan untuk biaya operasional. Adapun penerima penyaluran dana zakat lainnya, yaitu muallaf, riqab, gharimin dan ibnu sabil masing-masing memiliki proporsi tidak lebih dari 2 persen dari total penerima dana zakat.

Penyaluran terbesar diberikan untuk bidang sosial kemanusiaan sebesar 25,89\%, diikuti oleh bidang dakwah sebesar 22,56\%, bidang pendidikan sebesar 21,69\%, bidang ekonomi sebesar 20,33\% dan bidang kesehatan sebesar 9,52\%. Beberapa contoh program penyaluran yang dilakukan oleh BAZNAS di antaranya adalah program BAZNAS seperti tanggap bencana dan layanan aktif BAZNAS (bidang sosial kemanusiaan), Lembaga Beasiswa BAZNAS (bidang pendidikan), Rumah Sehat BAZNAS (bidang kesehatan), Lembaga Pemberdayaan Ekonomi Mustahik, BAZNAS Microfinance Desa, Balai Kurban, dan Zakat Community Development (bidang ekonomi), serta Mualaf Center BAZNAS dan Pusat Kajian Strategis BAZNAS (bidang dakwah). Program-program serupa juga dilakukan oleh OPZ lainnya.

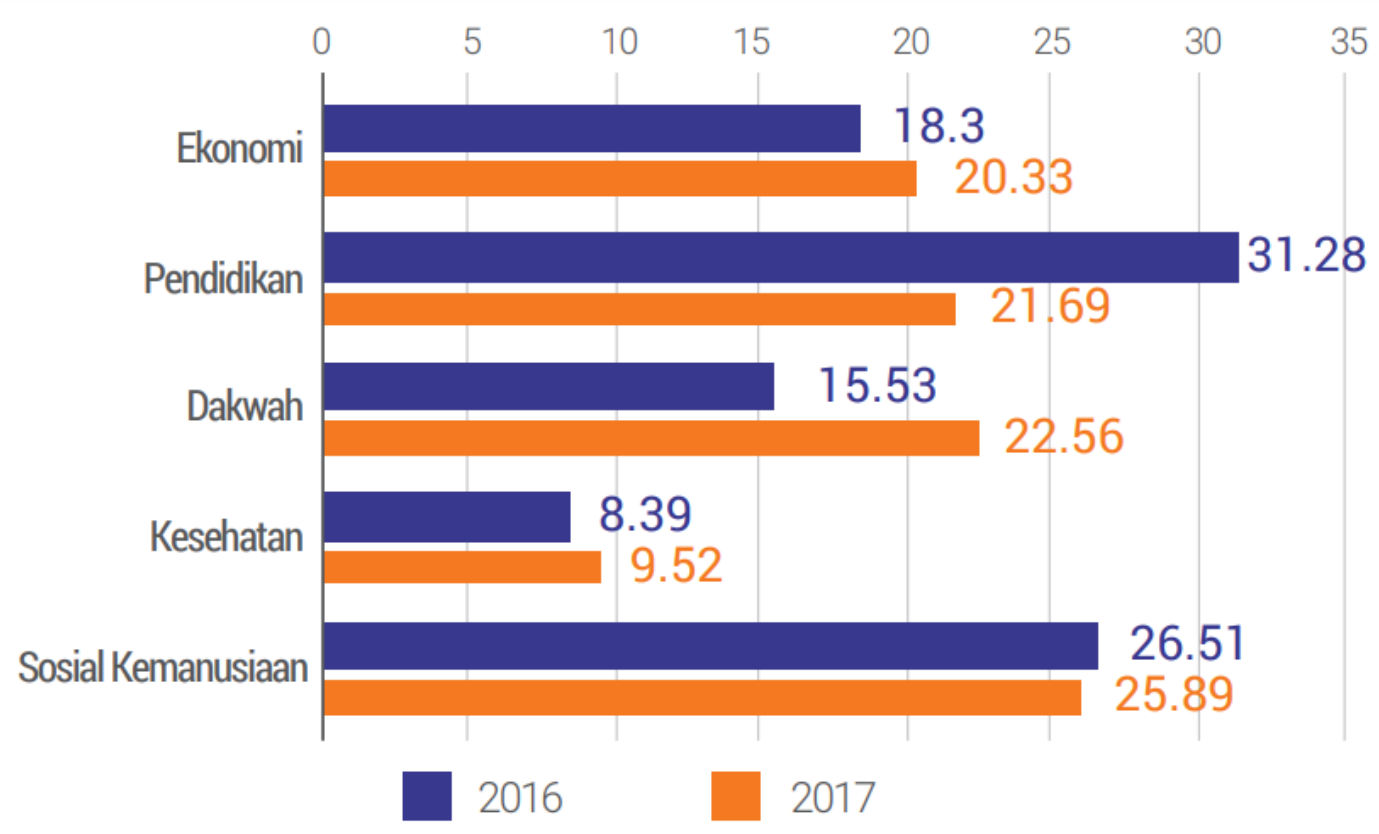

Gambar 5. Realisasi Penghimpunan dan Pertumbuhan Penghimpunan Dana ZIS 2008 2017

Sumber: BAZNAS, 2018

Dari berberapa perkembangan Industri Keuangan Syariah (IKS) yang sudah dipaparkan di atas, menjelaskan bahwa laju perkembangan LKS di Indonesia menunjukan trend positif. Hal ini merupakan harapan bahwa dikemudian hari Indonesia akan mampu menjadi pusat perkembangan Industri Keuangan Syariah (IKS) di dunia. 


\subsection{Strategi Peningkatan Industri Keuangan Syariah (IKS) dalam MEA}

Menurut Marthon (2007), keunggulan sistem ekonomi syariah, salah satunya adalah penyatuan nilai moral dan nilai spiritual di dalam sistem tersebut. Sistem perekonomian kontemporer hanya berfokus pada peningkatan utility dan materialisme tanpa menyentuh nilai spiritualisme dan etika kehidupan masyarakat. Padahal dalam kegiatan ekonomi, kedua hal tersebut merupakan satu kesatuan sehingga akan terjadi keseimbangan khususnya dalam proses transaksi. Mengabaikan kedua hal tersebutlah yang menyebabkan kehidupan ekonomi masyarakat tidak terkontrol karena terbebas dari koridor agama sehingga terjadi banyak penyelewengan seperti riba, monopoli, korupsi, dan lain sebagainya.

Lebih lanjut, sistem ekonomi syariah menempatkan manusia bukanlah sebagai sentral (antroposentrisme) tetapi manusia adalah sebagai hamba Tuhan (abid) yang harus mengabdi dan mengemban tugas yang dipercayakan oleh Allah kepadanya (khalifah). Ingin menguasai dan memiliki harta merupakan sifat dasar manusia. Meski membenarkan kepemilikan individu, namun kepemilikan tersebut tidaklah bersifat mutlak karena kepemilikan Allah merupakan kepemilikan murni dan hakiki. Dalam rangka keseimbangan yang merupakan karakteristik dari dasar ekonomi Islam, maka kepemilikan publik hadir sebagai penyeimbang kepemilikan individu (Marthon, 2007). Berbeda dengan sistem ekonomi kapitalis, pemenuhan kepuasan menjadi hal yang utama tanpa mempertimbangkan keseimbangan ekonomi di sekitarnya.

Lebih lanjut, ekonomi syariah mempunyai tujuan yang sama dengan tujuan Islam, yakni mencapai kebahagiaan di dunia dan akhirat melalui tatakehidupan yang baik dan terhormat. Tujuan tersebut dirumuskan dalam term falah (kemenangan). Dalam hal ini, falah di dunia mencakup tiga hal, yakni kelangsungan hidup, kebebasan keinginan, serta kekuatan dan kehormatan. Sedangkan falah di akhirat terdiri dari kelangsungan hidup yang abadi, kesejahteraan abadi, kemuliaan abadi, dan pengetahuan abadi (Rahmawati, 2009).

Sebagai negara dengan penduduk muslim terbesar, sudah selayaknya Indonesia menjadi pelopor dan kiblat pengembangan Industri Keuangan Syariah (IKS) di dunia. Hal ini bukan merupakan 'impian yang mustahil' karena potensi dan peluang Indonesia untuk menjadi global player keuangan syariah sangat besar khususnya dalam menghadapi MEA, diantaranya: (i) jumlah penduduk muslim yang besar menjadi potensi nasabah Industri Keuangan Syariah (IKS); (ii) prospek ekonomi yang cerah, tercermin dari pertumbuhan ekonomi yang relatif tinggi (kisaran 6,0\%-6,5\%) yang ditopang oleh fundamental ekonomi yang solid; (iii) peningkatan sovereign credit rating Indonesia menjadi investment grade yang akan meningkatkan minat investor untuk berinvestasi di sektor keuangan domestik, termasuk Industri Keuangan Syariah (IKS); dan (iv) memiliki sumber daya alam yang melimpah yang dapat dijadikan sebagai underlying transaksi Industri Keuangan Syariah (IKS). (Kolistiawan, 2017).

Sementara itu, Industri Keuangan Syariah (IKS) di Indonesia juga memiliki beberapa kekurangan. Pasar keuangan syariah di Indonesia memiliki tingkat kompleksitas yang lebih tinggi karena berorientasi pada ritel dan bersegmen khusus. Struktur dari pasar ini terdiri dari beberapa lapisan dengan batasan yang kurang jelas, yang tumpang tindih 
dan saling bergantung, sehingga kadang terjadi ketidaksinkronan antar sektor. Indonesia memiliki lebih banyak peraturan yang terkait dengan keuangan syariah dibandingkan negara-negara lain, tetapi peraturanperaturan ini tersebar dan kadang terbagi di antara banyak regulator. Perlu juga dipahami bahwa Indonesia mempunyai institusi keuangan syariah (baik formal maupun informal) dan konsumen keuangan syariah terbanyak di pasar tunggal mana pun, akan tetapi jumlah pastinya tidak diketahui karena keterbatasan data. Walaupun ada ketidaksempurnaan dan kekurangan, Industri Keuangan Syariah (IKS) di Indonesia telah meraih prestasi dengan mengembangkan aspek-aspek tertentu yang memberinya bentuk unik dari industri ini di dunia.

Terdapat beberapa alasan utama kurang berkembangnya kinerja Industri Keuangan Syariah (IKS) di Indonesia:

a. Kurangnya visi dan koordinasi antara berbagai pemangku kepentingan;

b. Kurangnya dukungan pemerintah untuk industri;

c. Kurangnya kesadaran di antara masyarakat umum dan sektor bisnis;

d. Relatif rendahnya kualitas dan kuantitas sumber daya manusia;

e. Konsentrasi industri yang berlebihan pada pasar ritel;

f. Kurangnya modal di seluruh Bank Umum Syariah dan Bank Perkreditan Rakyat Syariah;

g. Isu kapasitas di dalam institusi keuangan syariah dalam hal variasi produk, persaingan harga, sistem IT, tingkat pelayanan dan distribusi, dll;

h. Kurangnya likuiditas dalam pasar modal syariah;

i. Sumber pendanaan yang terbatas dalam sektor pasar modal syariah, perbankan, dan nonperbankan;

j. Kurangnya pengawasan dalam keuangan mikro; dan

k. Kurangnya transparansi dan tata kelola yang baik dalam sektor dana keagamaan syariah, termasuk dana Haji, Zakat dan Wakaf, dll.

Peran keuangan syariah dalam pembangunan ekonomi Indonesia Keuangan syariah bukan hanya mengenai preferensi agama, melainkan melalui Tujuan Syariah (Maqasid al Shariah), keuangan syariah mempunyai kekuatan laten dalam memainkan peranan penting dalam pemberdayaan individu dan komunitas, mempromosikan budaya wiraswasta, berinvestasi dalam ekonomi yang riil dan berkelanjutan sehingga mendatangkan manfaat bagi masyarakat luas dan ekonomi Indonesia. Kemudian, menjadikan Indonesia negara dengan ekonomi yang mandiri dan mampu menghadapi tantangan dari integrasi ASEAN mendatang; dan meningkatkan peran Indonesia dalam mendukung keuangan syariah mengingat Indonesia merupakan negara yang berpenduduk Muslim terbesar di dunia.

Guna meningkatkan infrastruktur dan kemampuan sistem keuangan syariah, mengatasi kesenjangan yang ada, memperbaiki kinerja kelembagaan, menciptakan peluang baru di pasar domestik dan internasional, dan memosisikan Indonesia sebagai pemain utama dalam keuangan syariah di dunia, diperlukan beberapa strategi utama, yaitu:

1) Membentuk Komite Nasional Keuangan Syariah melalui Keputusan Presiden. Komite ini akan bertindak sebagai badan "unggulan" nasional untuk mencapai visi keuangan syariah dan akan mengawasi pelaksanaan Masterplan;

2) Mengumumkan kebijakan pemerintah untuk mendukung keuangan syariah dengan menyediakan iklim usaha yang setara bagi Industri Keuangan Syariah (IKS). 
Kebijakan ini mendorong badan pemerintah dan BUMN untuk menempatkan sebagian dana mereka dalam Industri Keuangan Syariah (IKS), menawarkan pilihan produk keuangan syariah kepada staf mereka untuk menerima gaji di rekening bank syariah, dan memberikan pilihan manfaat seperti dana pensiun syariah dan perlindungan Takaful, dan produk lainnya;

3) Mendorong agar semua dana Haji, Zakat, Wakaf, dll. didepositokan dan dikelola di rekening bank syariah;

4) Meluncurkan program sosialisasi nasional untuk meningkatkan kesadaran di tingkat makro dan mikro;

5) Meluncurkan program pengembangan sumber daya manusia nasional dengan memperkenalkan kualifikasi profesional baru, mendorong alokasi anggaran untuk pelatihan, dan memperbaiki peraturan kepegawaian untuk meningkatkan kualitas sumber daya;

6) Meningkatkan kerangka kerja peraturan dengan mengonsolidasi kerangka kerja yang ada dan membuat perubahan atau mengeluarkan peraturan baru untuk mengatasi kesenjangan;

7) Meluncurkan kebijakan untuk meningkatkan penerbitan sukuk negara dan menerbitkan instrumen-instrumen baru yang terkait dengan proyek-proyek pembangunan infrastruktur, pertanian, dan pendidikan;

8) Meningkatkan infrastruktur pasar modal syariah dengan mendorong terbentuknya sukuk fund baru dan pialang utama syariah (primary dealers);

9) Menawarkan insentif yang terkait dengan instrumen-instrumen yang dirancang untuk mendanai proyek-proyek pembangunan ekonomi nasional seperti infrastruktur dan pertanian, dll;

10) Mengubah sistem akuntansi sukuk untuk mendorong likuiditas dalam pasar sekunder;

11) Memberi peluang terbentuknya bank investasi syariah untuk mengisi kesenjangan dalam sektor perbankan dan menjadi pemain utama dalam pembiayaan proyekproyek pembangunan besar;

12) Mengubah persyaratan permodalan untuk Bank Umum Syariah dan Bank Perkreditan Rakyat Syariah untuk meningkatkan kapasitas keuangan mereka bagi pertumbuhan di masa depan;

13) Mengonsolidasi sektor perbankan Syariah dengan melakukan merger untuk menciptakan pemain yang lebih besar dan kuat secara finansial;

14) Mengubah kondisi untuk pemisahan (spin off) Unit Usaha Syariah pada tahun 2023 untuk meminimalisir persoalan yang muncul dalam sektor perbankan Syariah;

15) Meningkatkan infrastruktur pasar bagi sektor nonperbankan syariah untuk mendorong aktivitas dalam sektor tersebut;

16) Meningkatkan peraturan dan pengawasan sektor keuangan mikro syariah;

17) Memberikan peluang terbentuknya berbagai dana APEX baru untuk lembaga keuangan mikro syariah;

18) Memberikan peluang terbentuknya penyedia jasa bantuan teknis dengan biaya yang terjangkau untuk sektor keuangan mikro syariah;

19) Mengubah struktur BAZNAS dan BWI dengan memberikan peran lebih untuk mengelola sektor Zakat dan Wakaf dan menguatkan peran Badan Pengelola Keuangan Haji (BPKH) dalam pengelolaan dana Haji; dan 
20) Meningkatkan kerangka kerja tata kelola syariah dengan memperkuat peran DSNMUI, memperkuat Komite Pengembangan Jasa Keuangan Syariah (KPJKS) dalam Otoritas Jasa Keuangan, menguatkan kesesuaian proses dan prosedur Syariah, dan memperkenalkan audit syariah internal.

Strategi utama tersebut mengacu pada Masterplan Ekonomi Syariah yang telah dirancang oleh Komite Nasional Ekonomi dan Keuangan Syariah. Sehingga jika pemerintah benar-benar menerapkan strategi tersebut maka Industri Keuangan Syariah (IKS) akan semakin kuat baik secara kinerja dan eksistensi di kancah dunia, khususnya di era Masyarakat Ekonomi ASEAN (MEA).

\section{Kesimpulan}

Kendati pertumbuhan Industri Keuangan Syariah (IKS) semakin kuat setiap tahun, ukuran keseluruhan dan dampak dari industri ini terhadap ekonomi nasional tetap kecil dibandingkan dengan industri keuangan umum. Padahal Indonesia merupakan negara yang memberikan peluang besar dalam pengembangan keuangan syariah di dunia, secara khusus di ASEAN. Tantangan pembentukan MEA pada 2015 lalu bagi Indonesia tidak hanya bersifat internal di dalam negeri. Persaingan antarpelaku usaha juga akan semakin ketat, baik dengan sesama pebisnis asal negara-negara ASEAN maupun regional lain. Tantangan persaingan yang ketat tersebut menuntut Indonesia terus menguatkan strateginya agar mampu bersaing di komunitas ekonomi ASEAN yang semakin terbuka.

Industri Keuangan Syariah (IKS) Indonesia dalam Global Islamic Economy Index (GIEI) 2020/2021 menempati posisi ke-4 di dunia, meningkat satu peringkat dari tahun 2019. Kemudian, Islamic Finance Development Indicators (IFDI) 2020 dari The Islamic Corporation for the Development (ICD), The Islamic Development Bank (IsDB) dan Revintiv menempatkan Indonesia pada posisi kedua keuangan syariah dunia, naik dari posisi empat pada tahun lalu. Peningkatan peringkat Indonesia di 2020 sangat dipengaruhi oleh indikator Pengetahuan (Knowledge), yang didalamnya termasuk peningkatan pendidikan dan riset keuangan syariah.

Kurang berkembangnya IKS saat ini dikarenakan beberapa alasan di antaraya, Kurangnya visi dan koordinasi antara berbagai pemangku kepentingan; Kurangnya dukungan pemerintah untuk industri; Kurangnya kesadaran di antara masyarakat umum dan sektor bisnis; Relatif rendahnya kualitas dan kuantitas sumber daya manusia; Konsentrasi industri yang berlebihan pada pasar ritel; Kurangnya modal di seluruh Bank Umum Syariah dan Bank Perkreditan Rakyat Syariah; Isu kapasitas di dalam institusi keuangan syariah dalam hal variasi produk, persaingan harga, sistem IT, tingkat pelayanan dan distribusi, dll; Kurangnya likuiditas dalam pasar modal syariah; Sumber pendanaan yang terbatas dalam sektor pasar modal syariah, perbankan, dan nonperbankan; Kurangnya pengawasan dalam keuangan mikro; dan Kurangnya transparansi dan tata kelola yang baik dalam sektor dana keagamaan syariah, termasuk dana Haji, Zakat dan Wakaf, dll.

Kekurang-kekurangan tersebut dapat menghambat peran Industri Keuangan Syariah Indonesia di kancah Masyarakat Ekonomi ASEAN (MEA). Guna meningkatkan infrastruktur dan kemampuan sistem keuangan syariah, mengatasi kesenjangan yang ada, memperbaiki kinerja kelembagaan, menciptakan peluang baru di pasar domestik dan internasional, dan memosisikan Indonesia sebagai pemain utama dalam keuangan syariah di ASEAN, diperlukan 20 strategi utama. 


\section{REFERENSI}

Andika, \& Aldy. (2020, Desember 28). Ekonomi dan Kenangan Syariab Indonesia Catat Prestasi Global di 2020. Retrieved Oktober 12, 2021, from KNEKS: https://knks.go.id/berita/342/ekonomi-dan-keuangan-syariah-indonesia-catatprestasi-global-di-2020?category $=1$

Ardianto, P. (2021, Juli 19). Bidik Market Share 25\%, Aset Asuransi Syariah Harus Tumbuh $30 \%$ per Tabun. Retrieved from investor.id: https://investor.id/finance/256060/bidik-market-share-25-aset-asuransi-syariahharus-tumbuh-30-per-tahun

Editor. (2021, Februari 19). Peran Indonesia dalam Bidang Ekonomi di ASEAN. Retrieved Oktober 24, 2021, from INDO MARITIM ID: https://indomaritim.id/peranindonesia-dalam-bidang-ekonomi-di-asean/

Editor. (2021, September 16). Tujuan Masyarakat Ekonomi ASEAN, Dampak \& Tantangan Bagi Indonesia. Retrieved Oktober 24, 2021, from tirto.id: https://tirto.id/tujuanmasyarakat-ekonomi-asean-dampak-tantangan-bagi-indonesia-gjst

Hidayat, Y. R. (2018). ANALISIS PELUANG DAN TANTANGAN LEMBAGA KEUANGAN SYARIAHUNTUK MENINGKATKAN DAYA SAING MENGHADAPI MASYARAKAT. Amwaluna: Jurnal Ekonomi dan Keuangan Syariah Vol.2, No.2, 165-181.

Khikmatin, A., \& Setianingsih, P. (2021). ANALISIS PELUANG DAN TANTANGAN LEMBAGA KEUANGAN SYARIAH DALAMUPAYA MENINGKATKAN DAYA SAING TERHADAP LEMBAGA KEUANGANKONVENSIONAL DI INDONESIA. Al-Iqtisahod: Jurnal Ekonomi Syariah, Vol. 3., No.1, 49-63.

KNEKS. (2019). One Data Center. Retrieved Oktober 12, 2021, from kneks.go.id: https://kneks.go.id/storage/upload/1573459280Masterplan\%20Eksyar_Preview.pdf

Kolistiawan, B. (2017). Tantangan Lembaga Keuangan Syariah dalam Mengahadapi Masyarakat Ekonomi ASEAN. Muqtasid 8(1), 54-64.

Mensari, R. D., \& Dzikra, A. (2017). Islam dan Lembaga Keuangan Syariah. AL-INTAJ Vol. 3, No. 1.

Otoritas Jasa Keuangan. (2021, Februari 25). Roadmap Pengembangan Perbankan Indonesia 2020 - 2025. Retrieved from https://www.ojk.go.id/id/berita-dan-kegiatan/infoterkini/Pages/-Roadmap-Pengembangan-Perbankan-Indonesia-2020---2025.aspx

Rijal, N. K. (2017). PELUANG EKONOMI SYARIAH PADA ERA MASYARAKAT EKONOMI ASEAN. Dauliyah, Vol. 2, No. 2, 259-278.

Salman, K. R. (2017). Akuntansi Perbankan Syariah : Berbasis PSAK Syariah. Jakarta: PT. Indeks. 